\title{
Morphology, Morphogenesis and Production of Tanzânia Grass, Submitted to Either Fixed or Variable Resting Period
}

\author{
Alberto Chambela Neto', José F. C. da Silva², Fermino Deresz ${ }^{3}$, Alberto M. Fernandes², \\ Bruno B. Deminicis ${ }^{4}$, Ismail R. Haddade1, Thiago L. Rosado ${ }^{1}$ \\ ${ }^{1}$ Federal Institute of Science Education and Technology Education of Espírito Santo, IFES, Santa Teresa Campus, \\ Santa Teresa, Brasil \\ ${ }^{2}$ State University of North Fluminense Darcy Ribeiro, UENF, Campos dos Goytacazes, Rio de Janeiro, \\ Brasil \\ ${ }^{3}$ National Center of Research in Milk Cattle-CNPGL, EMBRAPA, Coronel Pacheco Campus, Juiz de Fora, \\ Brasil \\ ${ }^{4}$ Federal University of Espírito Santo, Centro de Ciências Agrárias, CCA-UFES, Alegre, Brasil \\ Email: chambela@ifes.edu.br, ihaddade@gmail.com, thiagolr@ifes.edu.br, jif.coelho@hotmail.com, \\ alberto@uenf.br, deresz@acessa.com, brunodeminicis@gmail.com
}

Received 17 December 2014; accepted 2 January 2015; published 15 January 2015

Copyright (C) 2015 by authors and Scientific Research Publishing Inc.

This work is licensed under the Creative Commons Attribution International License (CC BY).

http://creativecommons.org/licenses/by/4.0/

c) (i) Open Access

\section{Abstract}

This work was carried out at Embrapa. Milk cattle and experimental field were located in Coronel Pacheco, MG, Brazil, in the period of December 2008 to May 2009. It was aimed to evaluate the effect of two different defoliation intervals on the morphology and morphogenetic characteristics of Tanzânia grass (Urochloa maxima) pasture. The treatments consisted of evaluations of 2 management strategies on pastures were: 1) IL95-consisted of the entry of animals into the pickets when the pasture reached $95 \%$ of interception of photosynthetically active radiation, with 3 days of picket occupation and 2) FIXED-pasture managed with 30 days of defoliation interval and 3 days of picket occupation. Ten cows (Holstein $\times \mathrm{Zebu}$ ) recently delivered were used to effectuate the grazer of the evaluated areas. The measured variables were analyzed by the mist model. The best model selection was based on the Akaike information criterion, in which the likelihood was evaluated for the different proposed models, where the composed symmetry had the better adjustment to the model. The management caused differences on the biomass production and on the morphological and morphogenetic structure of Tanzânia grass, in which the criterion of interception of photosynthetically active radiation allowed higher efficiency on the area usage. 


\section{Keywords}

\section{Defoliation Interval, Interception, Photosynthetically Active, Urochloa maxima}

\section{Introduction}

For a good pasture restoration after grazer it is necessary that a minimum quantity of remainder foliage is maintained so that the foliage may restore its reserves and allow a new defoliation. High pasture intensity, associated to a high defoliation may reduce pasture persistence, as low intensity and pasture frequency may promote fodder losses by senescence and even promote straw accumulation on the pasture.

The recommendations of the pasture rotative management, adopted nowadays, are mistaken, because in grazer under rotative allotment, the interval duration of successive defoliations is the variable which determines recuperation of the leave area index, and consequently, maximizes the fodder mass production. Usually, the determination of the defoliation interval is done in function of chronological criterions as number of days. However, despite the variations on the plant growth taxes and the seasonality fodder production, this criterion is not the best recommendation.

It is believed that the management proposals that respect the phenology and the physiology of each cultivar may promote improvement on the productivity and the pasture perennity indexes.

The objectives of the present work was to evaluate the biomass production and the morphological and morphogenetic characteristics of Tanzânia grass (Urochloa maxima) pasture subjected to 2 defoliation managements with fixed post pasture residue.

\section{Methods}

The experiment was carried out in EMBRAPA Milk Cattle, on the Experimental Field of Coronel Pacheco (CECP), in Coronel Pacheco-MG, Zona da Mata of the State of Minas Gerais, in December 2008 and May 2009. The coordinates of CECP is $21^{\circ} 32^{\prime} 38^{\prime \prime}$ South Latitude and at $43^{\circ} 15^{\prime} 10^{\prime \prime}$ West Longitude and the Altitude is 451 $\mathrm{m}$. The regional climate according to Koppen classification is Cwa mesothermal, characterized as rainy temperate climate in the summer with dry winter among June and September.

The experimental area consisted of 4 hectares of Tanzânia grass (Urochloa máxima), formed in 2006, non-irrigated, constituted of 11 areas with $909 \mathrm{~m}^{2}$ approximately each. The pasture was fertilized with $\mathrm{kg} \cdot \mathrm{ha}^{-1} \cdot \mathrm{year}{ }^{-1}$ of $\mathrm{N}$ and of $\mathrm{K}_{2} \mathrm{O}$ and $55 \mathrm{~kg} \cdot \mathrm{ha}^{-1} \cdot$ year $^{-1}$ of $\mathrm{P}_{2} \mathrm{O}_{5}$. Fertilization application was carried out broadcast, every time the animals were changed from area through the pasture cycles, in a way where the nutrients were provided in all the areas when pasture presented the same physiological age (with 1 day after pasture or after cutting lawn) according to the lower cycles depending on the adopted management. The rate of fertilizer application was approximately 3.7; 3.7 and $0.9 \mathrm{~kg}$ per area, in each cycle of $\mathrm{N}, \mathrm{K}_{2} \mathrm{O}$ and $\mathrm{P}_{2} \mathrm{O}_{5}$, respectively, at the commercial formula 20:05:20.

During the adaptation period, a pasture gradient was carried out, performing mechanical mowing to standardize the areas for the beginning of the evaluation period, respecting the expected residue of $30 \mathrm{~cm}$ after cows pasture.

Ten recently delivered cows (Holstein $\times$ Zebu) were used per treatment, and the same were constituted of 1 replication per area, consisting of 5 cows in each replication, managed in a rotative way in the 11 areas already mentioned.

The monitoring of photosynthetically active radiation interception or luminous interception (LI) by the pastured canopy was carried out under the condition of pre-pasture and during the period of January to May on each 7 days and when LI was next to the goal of 95\% the frequency of monitoring was of 2 days. A variation of $\pm 2 \%$ was considered as criterion of animals entrance into the pickets according to the little variation observed on the picket pasture mass. For the LI evaluations a canopy analyzer device-AccuPAR Linear PAR/LAI ceptometer, Model PAR-80 (Decagon Devices), was used with which readings in 10 areas points were carried out [1].

The pasture canopy height was determined using a ruler gauged in centimeters, with 20 points measured randomly per area. The height of every point corresponded to the medium canopy height around the ruler. Readings of plants height were carried out under pre-pasture condition, when the areas reached the stipulated LI level, and 
under post-pasture condition immediately after the animals exit.

The pasture total biomass, under pre and post-pasture conditions, was estimated with the assistance of a metallic frame with area of $1 \mathrm{~m}^{2}$, in 5 representative points of the medium canopy height, in each area. The material contained in each square was cut from $5 \mathrm{~cm}$ of the surface and weighted.

For the pasture morphological compounds evaluation a representative aliquot was withdrawn from the samples harvested for the pasture total mass, on the pre and post-pasture determination. This aliquot was separated on the fractions foliar blade thickness, stem (stem + sheath) and dead material, which were weighted and dried in a forced air circulation chamber at $55^{\circ} \mathrm{C}$ until constant weight. The pasture biomass values were converted to ton of MS $\cdot \mathrm{ha}^{-1}$ and the morphological compounds expressed as proportion $\left(\mathrm{g} \cdot \mathrm{kg}^{-1}\right)$ of pasture total mass.

The pasture accumulation (Ton. MS $\cdot \mathrm{ha}^{-1}$ ) was calculated from the difference between the pasture mass on the previous post-pasture and on the actual pre-pasture [2]-[4].

Eighteen clumps were set in each area replication, with 6 per area (3 areas), on which 2 tillers with wire "rings" colored and evaluated were identified, initially, the number of alive pastured tillers; and from this moment, the following characteristics were weekly evaluated: the total leaf number by tiller (TLN), the number of alive leaves by tiller (NAL), the number of total expanded leaves (NTEL), the leaves medium length (LML) and from the stem (SML), originated during the evaluation period, in each experimental unit, as described by [2]-[4].

For the morphogenesis evaluation, following the determinations of the same authors, the leaf lengthened tax (LLT), stem lengthened tax (SLT), leaves appearance tax (LAT) and Phyllochron (PHY), which represents the time interval, on days, for the appearance of a leaf on a tiller were measured.

The variables measured on the present study were analyzed by the adjustment of the following mist model: Yijk $=\mu+\alpha \mathrm{i}+\mathrm{Rj}(\mathrm{i})+\beta \mathrm{k}+\alpha \beta \mathrm{ik}+$ eijk, where Yijk corresponds to the observation carried out on the $\mathrm{j}$-th area on which the $\mathrm{i}$-th treatment was provided during the k-th period; $\mu$ represents the general average; $\alpha \mathrm{i}$ corresponds to the effect of the $i$-th treatment $(i=1,2)$; $\operatorname{Rj}(i)$ represents the effect of the $j$-th area $(j=1,2)$ inside the $\mathrm{i}$-th treatment; $\beta \mathrm{k}$ represents the effect of the $\mathrm{k}$-th period $(\mathrm{k}=1,2,3,4) ; \alpha \beta \mathrm{ik}$ is the interaction among the $\mathrm{i}$-th treatment and the k-th period; and eijk corresponds to the random error, supposed normal, independent and identically distributed, with average 0 and variance $\sigma^{2}$.

The parameters were estimated with the MIXED procedure of SAS (version 9, SAS System Inc., Cary, NC, USA), in which the selection of the better model was based on the criterion of information [5]-[7]. One of the criterions was the probability of likelihood, calculated from the Arkaike criterion for the different proposed models, as suggested by Vieira [8]. The variance and covariance tested structures were: variance compounds, composed symmetry, auto-regressive correlations of first order, Toeplitz structure, as the unrestricted structure SAS $^{\circledR}$ for Mixed Models.

After the individual probability had been calculated for each model, the results indicated that the same were equivalent, the variance compound was prioritized, because the same presented the best adjustment to the proposed model.

\section{Results and Discussion}

It is important to relate that, according to the adopted treatments, the cycles duration among pasture varied on treatment IL95 (Table 1).

On the morphogenetic and structure evaluations of the pasture, no difference was observed for the variables: total leaf number by tiller, number of alive leaves by tiller, stem medium length and leaves appearance tax.

The stability of number of alive leaves by tiller is suggested as criterion on the determination of the plant cut moment and the interval of defoliation in rotative pasture systems [9]. It is probable that, due to the short period of evaluation, the number of alive leaves by tiller had not still stabilized, as observed by Andrade [10] in a work with elephant grass (Pennisetum purpureum Schum. cv. Napier) and Gomide [9] with Mombaça-grass (Urochloa maxima).

Table 1. Duration of the cycles among pasture experimental period.

\begin{tabular}{ccccc}
\hline \multirow{2}{*}{ Treatments } & \multicolumn{4}{c}{ Duration days of pasture cycles } \\
\cline { 2 - 5 } & February & March & April & May \\
\hline IL 95 & 24 & 24 & 27 & 30 \\
Fixed & 30 & 30 & 30 & 30 \\
\hline
\end{tabular}


Although the stem lengthened tax has increased with the defoliation interval, the same did not produce effect on the stem medium length (Table 2).

The stem lengthened tax did not vary among cycles, but presented significant differences among treatments, on cycles 1 and 2, where the treatment with FIXED defoliation interval resulted in higher taxes. This higher stem lengthen, was probably caused by the higher defoliation interval on this treatment, what allowed this one to be pastured in a more advanced physiological maturity stage than the pasture on treatment IL95.

The higher stem lengthen may also have been influenced by the higher shading occurred on the pasture canopy basis of the Fixed treatment, once that with the defoliation interval adoption, this one when pastured presented total interception of incident radiation by the leaves.

Alexandrino [10] affirmed that as the canopy closes intercepting almost all the incident luminous radiation, the senescence and older leaves death process is intensified, at the same time the tiller is inhibited. Under these conditions, the tiller process is replaced by the process of stem lengthen, propitiating continuation of the mass increment of the closed canopy. This way, there would happen alteration on the partition of photoassimilated compounds for the stem formation on detriment to the tiller.

The defoliation interval is one of the most important factors of the pasture rotative management, because it affects from the calculation of the area number that is necessary to productive and structural canopy characteristics [11]-[13]. Despite the importance, the implementation of this management has to be based on a chronological criterion, while the vegetable growth, or more specifically, in the case of pasture, it responds to environment and management factors [9]. The number of total expanded leaves was higher on the cycles between pasture 1 and 2, in both the treatments (Table 3). Probably because on these periods the higher medium temperatures and precipitations occurred, what propitiated higher leaf lengthened tax (Table 2).

Table 2. Stem medium lengthened taxes and medium leaves lengthen taxes of Tanzânia grass on the cycles among pasture.

\begin{tabular}{|c|c|c|c|c|c|}
\hline \multicolumn{6}{|c|}{ Stem medium lengthened taxes $\left(\mathrm{mm} \cdot\right.$ tiller $^{-1} \cdot$ day $^{-1}$ ) } \\
\hline Treatments & Cycle 1 & Cycle 2 & Cycle 3 & Cycle 4 & P-values (Cycles) \\
\hline IL95 & $6.4 \mathrm{~b}$ & $6.0 \mathrm{~b}$ & $6.6 \mathrm{a}$ & $7.1 \mathrm{a}$ & 0.891 \\
\hline Fixed & $10.7 \mathrm{a}$ & $10.4 \mathrm{a}$ & $9.7 \mathrm{a}$ & $9.9 \mathrm{a}$ & 0.894 \\
\hline P-values (Treatments) & 0.018 & 0.019 & 0.061 & 0.078 & $\mathrm{CV} \%=16.36$ \\
\hline \multicolumn{6}{|c|}{ Medium leaves lengthen taxes } \\
\hline IL95 & $7.2 \mathrm{~A}$ & $7.3 \mathrm{~A}$ & $6.3 \mathrm{~B}$ & $6.25 \mathrm{~B}$ & $<0.001$ \\
\hline Fixed & $7.2 \mathrm{~A}$ & $7.3 \mathrm{~A}$ & $6.3 \mathrm{~B}$ & $6.25 \mathrm{~B}$ & $<0.001$ \\
\hline$P$-values (Treatments) & 1.0 & 1.0 & 0.309 & 1.0 & $\mathrm{CV} \%=1.33$ \\
\hline
\end{tabular}

Within a column, means without a common superscript differ $(\alpha=0.05)$. Within a row, means without a common superscript differ $(\alpha=0.05)$.

Table 3. Medium number of total expanded leaves, leaves medium length and medium time necessary for the appearance of 1 leaf on the tiller (Phyllochron) of Tanzânia grass on the cycles among pasture.

\begin{tabular}{|c|c|c|c|c|c|}
\hline \multicolumn{6}{|c|}{ Medium number of total expanded leaves } \\
\hline Treatments & Cycle 1 & Cycle 2 & Cycle 3 & Cycle 4 & $P$-values (Cycles) \\
\hline IL 95 & $3.5 \mathrm{a}$ & $4.2 \mathrm{a}$ & $2.5 \mathrm{~b}$ & $2.7 \mathrm{~b}$ & 0.035 \\
\hline Fixed & $4.2 \mathrm{a}$ & $3.7 \mathrm{a}$ & $2.5 \mathrm{~b}$ & $2.5 \mathrm{~b}$ & 0.022 \\
\hline P-values (Treatments) & 0.199 & 0.357 & 1.0 & 0.053 & $\mathrm{CV} \%=14.03$ \\
\hline \multicolumn{6}{|c|}{ Leaves medium length (cm) } \\
\hline IL 95 & 74.0 a B & 75.7 a B & $64.1 \mathrm{~b} \mathrm{~B}$ & $64.0 \mathrm{~b} \mathrm{~B}$ & $<0.001$ \\
\hline Fixed & 77.5 a $\mathrm{A}$ & 77.9 а A & $73.4 \mathrm{~b} \mathrm{~A}$ & $74.4 \mathrm{~b} \mathrm{~A}$ & $<0.001$ \\
\hline P-values (Treatments) & $<0.001$ & $<0.001$ & $<0.001$ & $<0.001$ & $\mathrm{CV} \%=0.79$ \\
\hline \multicolumn{6}{|c|}{ Phyllochron (day·leaves ${ }^{-1}$ ) } \\
\hline IL 95 & $7.0 \mathrm{~b}$ & $6.0 \mathrm{~b}$ & $10.0 \mathrm{a}$ & $9.3 \mathrm{a}$ & 0.037 \\
\hline Fixed & $6.2 \mathrm{~b}$ & $7.3 \mathrm{~b}$ & $10.0 \mathrm{a}$ & $10.0 \mathrm{a}$ & 0.033 \\
\hline$P$-values (Treatments) & 0.488 & 0.302 & 1.0 & 0.565 & $\mathrm{CV} \%=14.03$ \\
\hline
\end{tabular}

Within a column, means without a common superscript differ $(\alpha=0.05)$. Within a row, means without a common superscript differ $(\alpha=0.05)$. 
The final size of the leaf is determined by the relation lengthen tax: leaves appearance tax. The leaves appearance tax is inversely correlated to the final size of the leaf [14].

For the leaves lengthen tax, effect between the treatments was not observed, only among cycles, where the higher taxes happened on cycles 1 and 2 (February and March), once that the climatic conditions which occurred during this period were more favorable to the gramineous growth, mainly due to precipitation which substantially decreased, on the subsequent periods. The leaves lengthen is extremely dependent on water availability, once it affects cellular division and lengthen [9]. On this work, similar values to the ones related here are observed.

Add to that, the lower water availability may cause the loss of cellular turgescence in response to the soil hydric potential fall [15] what would help to reduce the leaf lengthen tax [16] and would affect, by consequence, the leaf size. The leaves medium length was also higher among pasture 1 and 2, in both treatments. The treatment with FIXED defoliation interval had already presented leaves with higher length than the treatment IL95, once that in the months of February, March, and April, the cycles between pasture in this treatment were lower for 30 days, what allowed more growing days on the FIXED treatment (Table 3).

The leaves appearance tax did not vary among the treatments and among the evaluated periods. Lemaire and Chapman [17] affirmed that the leaves appearance tax tends to decrease with the increase of plants height and decrease of the number of leaves, resulting in lower tiller, although the plants medium height had varied on the evaluated periods, this variation was not large enough to significantly alter the leaves appearance tax of the treatments. However the values observed on this work are similar to the ones obtained by [9] [18] [19] (Table 4).

The phyllochron represents the number of days that are necessary for the appearance of a leaf on the tiller, and varies according to the pasture species, but for the same genotype responds to the time of the year depending on the light conditions, temperature and soil humidity [20].

The higher period for leaves appearance during the cycles 3 and 4 evidences the unfavorable situation of the plants as they are submitted to low precipitation, temperature and photoperiod decrease (Table 3).

The proportion of senescent tissue is low when compared to the proportion of vegetative tissues (caulis and leaves) and as the defoliation interval increases, it is observed an increase on the senescent material size. The same is observed as the treatments are compared, where treatment FIXED allowed higher proportions of senescent material while the defoliation interval was higher than the treatment IL95 (Table 4).

The caulis proportion varied within the treatments through the experimental period and among the treatments on the cycles 1 and 2 (Table 5). Although the stems medium length had not varied during the experimental period, the higher proportion of caulis observed on the cycles between pasture 3 and 4 was consonant to the higher taxes of stem lengthen observed at this same period (Table 2).

Table 4. Medium height of Tanzânia grass under pre-pasture condition and biomass medium production under pre-pasture and post-pasture condition.

\begin{tabular}{|c|c|c|c|c|c|}
\hline \multicolumn{6}{|c|}{ Medium height (m) under pre-pasture condition } \\
\hline Treatments & Cycle 1 & Cycle 2 & Cycle 3 & Cycle 4 & $P$-values (Cycles) \\
\hline IL95 & 0.97 a $\mathrm{A}$ & 1.01 a A & 1.02 a B & 0.95 a B & 0.075 \\
\hline Fixed & $1.01 \mathrm{~b} \mathrm{~A}$ & $0.99 \mathrm{ab} \mathrm{A}$ & 1.08 a $\mathrm{A}$ & $1.01 \mathrm{~b} \mathrm{~A}$ & 0.006 \\
\hline$P$-values (Treatments) & 0.116 & 0.394 & 0.025 & 0.045 & $C V \%=0.05$ \\
\hline \multicolumn{6}{|c|}{ Biomass medium production ( $\mathrm{T}$ of $\mathrm{DM} \cdot \mathrm{ha}^{-1}$ ) under pre-pasture condition } \\
\hline IL95 & $2.04 \mathrm{~b}$ & $3.27 \mathrm{ab}$ & 4.99 a & $2.84 \mathrm{ab}$ & 0.008 \\
\hline Fixed & $3.02 \mathrm{~b}$ & $4.55 \mathrm{ab}$ & $5.65 \mathrm{a}$ & $2.81 \mathrm{ab}$ & 0.006 \\
\hline$P$-values (Treatments) & 0.328 & 0.214 & 0.506 & 0.975 & $\mathrm{CV} \%=23.42$ \\
\hline \multicolumn{6}{|c|}{ Biomass medium production ( $\mathrm{T}$ of $\mathrm{DM} \cdot \mathrm{ha}^{-1}$ ) under post-pasture condition } \\
\hline IL95 & $1.12 \mathrm{a}$ & $2.40 \mathrm{a}$ & $1.58 \mathrm{a}$ & $2.24 \mathrm{a}$ & 0.079 \\
\hline Fixed & $1.08 \mathrm{c}$ & $3.00 \mathrm{a}$ & 1.58 bc & $2.28 \mathrm{ab}$ & 0.019 \\
\hline$P$-values (Treatments) & 0.938 & 0.212 & 1.0 & 0.921 & $\mathrm{CV} \%=9.84$ \\
\hline
\end{tabular}

Within a row, means without a common lowercase superscript differ $(\alpha=0.05)$. Within a column, means without a common uppercase superscript differ $(\alpha=0.05)$. 
Table 5. Leaves proportion, caulis proportion and senescent matter proportion of Tanzânia grass on the cycles among pasture.

\begin{tabular}{|c|c|c|c|c|c|}
\hline \multicolumn{6}{|c|}{ Leaves proportion (g. $\left.\mathrm{kg}^{-1} \mathrm{DM}\right)$} \\
\hline Treatments & Cycle 1 & Cycle 2 & Cycle 3 & Cycle 4 & $P$-values (Cycles) \\
\hline IL95 & 522.9 a A & 517.5 a A & $346.1 \mathrm{~b} \mathrm{~A}$ & 343.5 b B & $<0.001$ \\
\hline Fixed & 456.8 a B & 453.6 a B & $352.1 \mathrm{~b} \mathrm{~A}$ & $357.2 \mathrm{~b}$ A & $<0.001$ \\
\hline$P$-values (Treatments) & $<0.001$ & $<0.001$ & 0.103 & 0.004 & $\mathrm{CV} \%=0.46$ \\
\hline \multicolumn{6}{|c|}{ Caulis proportion ( $\left.\mathrm{g} \cdot \mathrm{kg}^{-1} \mathrm{DM}\right)$} \\
\hline IL95 & $437.4 \mathrm{~b}$ B & $436.5 \mathrm{~b} \mathrm{~B}$ & 586.4 a A & 583.3 a $\mathrm{A}$ & $<0.001$ \\
\hline Fixed & $489.0 \mathrm{~b} \mathrm{~A}$ & $491.2 \mathrm{~b}$ A & 587.4 a A & 577.7 a A & $<0.001$ \\
\hline$P$-values (Treatments) & $<0.001$ & $<0.001$ & 0.835 & 0.264 & $C V \%=0.58$ \\
\hline \multicolumn{6}{|c|}{ Senescent matter proportion (g. $\left.\mathrm{kg}^{-1} \mathrm{DM}\right)$} \\
\hline IL95 & 39.7 b B & $46.0 \mathrm{~b} \mathrm{~B}$ & 67.5 a A & 73.2 a A & $<0.001$ \\
\hline Fixed & $54.2 \mathrm{~b} \mathrm{~A}$ & $55.2 \mathrm{~b} \mathrm{~A}$ & 60.5 a A & 65.1 a $A$ & 0.045 \\
\hline$P$-values (Treatments) & 0.007 & 0.005 & 0.081 & 0.053 & $\mathrm{CV} \%=2.77$ \\
\hline
\end{tabular}

Within a row, means without a common lowercase superscript differ $(\alpha=0.05)$. Within a column, means without a common uppercase superscript differ $(\alpha=0.05)$.

These proportions may be an indicator that with the precipitation, medium temperature and the number of rainy days reduction on this period, the photosynthetic tax of Tanzânia grass may have decreased and allowed higher caulis lengthen.

As the treatments are compared, it is observed higher caulis proportion to the FIXED treatment in relation to IL95, on the cycles 1 and 2. It is possible that the higher defoliation interval on the cycles has allowed these higher proportions, once the analogous values are observed to the proportion of leaves (Table 5).

The proportion of leaves varied within the treatments through the experimental period and among the treatments, on the cycles 1, 2 and 4. Although the total number of leaves, of alive leaves by tiller and the leaves appearance tax had not varied during the experimental period, the higher proportion of leaves observed on cycle 1 and 2 was consonant to the higher leaves lengthen taxes (Table 2) and higher leaves medium lengthen observed at this same period (Table 3).

As the bovine pasture they tend to take the plants superior layer which contains more leaves, that is, there is a preference by leaves in detriment to the caulis. This selectiveness occurs due to the higher protein proportion and fiber lower proportions, what consequently promotes higher leaves digestibility in relation to the caulis [21].

The number of alive leaves by tiller, the equivalence among the lengthen tax and leaf senescence by tiller, as well as the stem lengthen reduction are some of the criterions that are presented as advisors of caespitose tropical gramineous plants management [22].

Therefore, the adoption of isolated variables for the determination of the management may lead to wrong conclusions [23] mainly when pasture formed with gramineous of stem precocious lengthen, as capim-Tanzânia are evaluated.

More detailed studies about the components of pasture gramineous production are important to understand the leaf area restoration process of the plants after defoliation with biomass and pasture height analysis [24].

The pasture biomass production and the pasture height under pre-pasture condition presented significant effect among the pasture cycles, what demonstrated that under these conditions, as the results observed by Carvalho [25], the different defoliation intervals observed through the cycles, promoted higher biomass production on the treatments (Table 4).

The lower pasture biomass production that occurred on cycle 1 in relation to cycle 3 , in both treatments, may be resulting from the pasture gradient carried out in the previous month, once that in this month the areas were mechanically mowed aiming to standardize a pasture gradient for the beginning of the evaluation period. This period was the only one where it was possible to obtain post-pasture residue of $30 \mathrm{~cm}$, and this way, cycle 1 was 
the only where did not occur biomass residue previously to its begin, what may have contributed to these lower observed values. On cycles 2 and 4 significant difference was not observed in relation to the other cycles.

Difference on biomass production among treatments did not occur. The pasture plants height on the cycles of the FIXED treatment, in a certain way, followed biomass production once that on cycle 3 it was verified the higher height mean, superior to cycles 1 and 4 and not differing from cycle 2 . The cycles 1,2 and 4 did not differ from each other.

In as much biomass production as the pasture canopy height on pre-pasture may have been influenced by pasture efficiency of the previous cycle, once on cycle 2 it was observed the higher post-pasture residue and higher pasture residual height, what conferred to cycle 3 higher quantity of dead material that integrated the manual samples harvested on this cycle.

Among treatments, it is observed that on cycles 1 and 2 there was no difference on height, however the cycles 3 and 4 from the FIXED treatment were superior to the ones observed on IL95.

Despite the defoliation intervals have been shorter (variation form 24 to 30 days), it was not sufficient to control the pasture canopy height which varied from 0.95 to $1.05 \mathrm{~m}$ among the pasture cycles. Similar responses were observed by Uebele (2002) and Cândido et al. (2005). This way, the pasture height may compromise the pasture quality, due to the higher lignin proportion observed on these pasture cycles and affect the dry matter consumption, once with higher pasture offer, the animal may carry out better harvest of the same due to a ampler pasture horizon [26] (Table 6).

The residual post-pasture biomass did not vary between treatments, only among pasture cycles of the FIXED treatment. The residual biomass on cycle 2 was superior to the cycles 1 and 3 and did not differ from cycle 4 (Table 4). Cycle 4 did not differ from cycle 3, but it was superior to cycle 1 . The lower residual biomass under post-pasture condition observed on cycle 1 , is probably due to the initial formation of the system, when mechanical mowing was performed in the month before the first cycle, because it was the only period evaluated where it was possible to obtain the desired residues of $30 \mathrm{~cm}$ on the post-pasture.

Uebele [27] did not maintain in $30 \mathrm{~cm}$ the residue of pasture canopy in mombaça grass under pasture with intermittent allotment, observing relatively long defoliation interval, what allowed the almost complete light interception, resulting from the selective pasture applied by the bullocks and from their low pasture efficiency in an inferior horizon from that one defined by the poles height.

The same effect may have occurred with Tanzânia grass in this study, once the allotment with 5 UAs/ha may not have been the ideal, where low pasture pressure has been applied on pasture and the animals would have better chance to select the feed, what turns the losses higher and consequently increases the pasture residual height.

Under post-pasture condition, statistical difference was not observed, where the P-values observed for treatment, for pasture cycle and for treatment $\mathrm{x}$ cycle interaction were 0.076 ; 0.082 and 0.251 , respectively.

The average observed on the treatments among pasture cycles $(50 \mathrm{~cm})$ was almost twice higher than the one considered ideal, nowadays, for Tanzânia grass $(30 \mathrm{~cm})$, where in more extreme periods the residual height stayed next to $60 \mathrm{~cm}$.

\section{Conclusion}

The reduction of the pasture cycles regarding the evaluation of the photosynthetically active radiation interception affects various morphological and morphogenetic components, but it is not sufficient enough to affect in a significant way the biomass production of Tanzânia grass.

Table 6. Average ( $\mathrm{g} \cdot \mathrm{kg}^{-1}$ of DM) of the lignin proportion on Tanzânia grass.

\begin{tabular}{cccccc}
\hline Treatments & Cycle 1 & Cycle 2 & Cycle 3 & Cycle 4 & $P$-values (Cycles) \\
\hline IL95 & $57.1 \mathrm{a} \mathrm{A}$ & $66.7 \mathrm{a} \mathrm{A}$ & $66.1 \mathrm{a} \mathrm{A}$ & $69.3 \mathrm{a} \mathrm{B}$ & 0.362 \\
Fixed & $59.9 \mathrm{~b} \mathrm{~A}$ & $79.4 \mathrm{ab} \mathrm{A}$ & $66.0 \mathrm{ab} \mathrm{A}$ & $86.7 \mathrm{a} \mathrm{A}$ & 0.033 \\
$P$-values (Treatments) & 0.691 & 0.172 & 0.983 & 0.045 & CV\% $=6.16$ \\
\hline
\end{tabular}

Within a row, means without a common lowercase superscript differ $(\alpha=0.05)$. Within a column, means without a common uppercase superscript differ $(\alpha=0.05)$. 


\section{Acknowledgements}

Sincere thanks to the following institutions and the people: To FAPEMIG, by financing this research project and to EMBRAPA-Milk Cattle, by the area provided for the experiment realization.

\section{References}

[1] Carnevalli, R.A. (2003) Dynamics of Regrowth of Pastures Mombaça Grass Undergoing Intermittent Defoliation Regimes. PhD Dissertation, College of Agriculture Luiz de Queiroz, Piracicaba.

[2] Carvalho, C.A.B., Silva, S.C., Sbrissia, A.F., Pinto, L.F.M., Carnevalli, R.A., Fagundes, J.L. and Pedreira, C.G.S. (2000) Tiller Demographics and Rates of Dry Matter Accumulation in Grass “Tifton 85” Grazing. Scientia Agricola, 57, 591-600. http://dx.doi.org/10.1590/S0103-90162000000400001

[3] Paciullo, D.S.C., Deresz, F., Aroeira, L.J.M., Morenz, M.J.F. and Verneque, R.S. (2003) Morphogenesis and Accumulation of Leaf Biomass in Grazing Elephant Grass Evaluated at Different Times of the Year. Brazilian Agricultural Research, 38, 881-887.

[4] Paciullo, D.S.C., Campos, N.R., Gomide, C.A.M., de Castro, C.R.T., Tavela, R.C. and Rossiello, R.O.P. (2008) Growth of Signal Grass Influenced by the Degree of Shading and Season of the Year. Brazilian Agricultural Research, 43, 917-923.

[5] Akaike, H. (1974) A New Look at the Statistical Model Identification. IEEE Transactions on Automatic Control, 19, 716-723. http://dx.doi.org/10.1109/TAC.1974.1100705

[6] Motulsky, H.J. and Cristopoulos, A. (2003) Fitting Models to Biological Data Using Linear and Nonlinear Regression. A Practical Guide to Curve Fitting. 1 Edition, GraphPad Software Inc., San Diego.

[7] Burnham, K.P. and Anderson, D.R. (2004) Multimodel Inference: Understanding AIC and BIC in Model Selection. Sociological Methods and Research, 33, 261-304. http://dx.doi.org/10.1177/0049124104268644

[8] Vieira, R.A.M., Tedeschi, L.O. and Cannas, A. (2008) A Generalized Compartmental Model to Estimate the Fibre Mass in the Ruminoreticulum: 1. Estimating Parameters of Digestion. Journal of Theoretical Biology, 255, 345-356. http://dx.doi.org/10.1016/j.jtbi.2008.08.014

[9] Gomide, C.A.M., Gomide, J.A. and Alexandrino, E. (2007) Structural Characteristics and Production of Forage in Mombaça Grass Undergoing Periods of Rest. Brazilian Agricultural Research, 42, 1487-1494.

[10] Alexandrino, E., Gomide, J.A. and Gomide, C.A.M. (2005) Growth and Canopy Development of Panicum maximum cv. Mombasa. Brazilian Journal of Animal Science, 34, 2164-2173.

[11] Santos, P.M., Corsi, M. and Balsalobre, M.A.A. (1999) Effect of Grazing Frequency and Season of the Year on Yield and Quality in Panicum maximum cvs. Tanzania and Mombasa. Brazilian Journal of Animal Science, 28, 244-249.

[12] Cândido, M.J.D., Alexandrino, E. and Gomide, J.A. (2005) Interval Length of Defoliation and Canopy Growth of Panicum maximum cv. Mombasa under Rotational Stocking. Brazilian Journal of Animal Science, 34, 398-405.

[13] Barbosa, R.A., Nascimento Jr., D., Euclides, V.P.B., Carneiro Da Silva, S., Zimmer, A.H. and de A. Torres Jr., R.A. (2007) Tanzania Grass Subjected to Combinations of Intensity and Frequency of Grazing. Brazilian Agricultural Research, 42, 329-340.

[14] Nabinger, C. and Pontes, L.S. (2001) Morphogenesis of Forage and Pasture Structure. Proceedings of the 38 Annual Meeting of the Brazilian Society of Animal Science, Piracicaba, 23-26 July 2001, 755-770.

[15] Taiz, L. and Zeiger, E. (1998) Plant Physiology. 2nd Edition, Sinauer Associates, Sunderland.

[16] Mattos, J.L.S., Gomide, J.A. and Martinez, C.A. (2005) Growth of Brachiaria Species under Water Deficit in Greenhouse. Brazilian Journal of Animal Science, 34, 746-754.

[17] Lemaire, G. and Chapman, D. (1996) Tissue Flows in Grazed Plant Communities. In: Hodgson, J. and Illius, A.W., Eds., The Ecology and Management of Grazing Systems, CAB International, Wallingford, 3-36.

[18] Andrade, A.C. (2001) Morphogenesis, Growth Analysis and Chemical Composition of Elephant Grass (Pennisetum purpureum Schum. Bhp. Napier) Fertilized and Irrigated Grazing. PhD Dissertation, Federal University of Viçosa, Viçosa.

[19] Almeida, E.X., Maraschin, G.E., Harthmann, O.E.L., Ribeiro Filho, H.M.N. and Setelich, E.A. (2000) Herbage Allowance of Dwarf Elephant Grass "Mott” and the Dynamics of Pasture. Brazilian Journal of Animal Science, 29, 1281-1287.

[20] Wilhelm, W.W. and McMaster, G.S. (1995) Importance of the Phyllochron in Studying Development and Growth in Grasses. Crop Science, 35, 1-3. http://dx.doi.org/10.2135/cropsci1995.0011183X003500010001x

[21] Hall, S.J.G. (2002) The Ethology of Domestic Animals: An Introductory Text. CABI Publishing, Wallingford, Oxon, 
New York.

[22] Gomide, C.A.M., Gomide, J.A. and Paciullo, D.S.C. (2006) Morphogenesis as Tool for Pasture Management. Brazilian Journal of Animal Science, 35, 554-579.

[23] Lemaire, G. and Agnusdei, M. (1999) Leaf Tissue Turn-Over and Efficiency of Herbage Utilization. In: Anais simpósio Internacional “Grassland Ecophysiology and Grazing Ecology,” UFPR, Curitiba, 165-186.

[24] Pedreira, C.G.S., Mello, A.C.L. and Otani, L. (2001) The Production of Forage in Pasture. In: Mattos, W.R.S., Ed., Livestock Production in the Vision of Brazilian, FEALQ, Piracicaba, 772-807.

[25] Carvalho, P.C.F., Marçal, G.K., Ribeiro Filho, H.M.N., Poli, C.H.E.C., Moraes, A. and Delagarde, R. (2001) Upland Pastures Can Limit the Consumption of Animals. Proceedings of the 38 Annual Meeting of the Brazilian Society of Animal Science, Piracicaba, 23-26 July 2001 (cd-rom).

[26] Carvalho, P.C.F., Oliveira, J.O.R., Pontes, L.S., da Silveira, E.O., Poli, C.H.E.C., Rübensam, J.M. and dos Santos, R.J. (2006) Características de carcaça de cordeiros em pastagem de azevém manejada em diferentes alturas. Pesquisa Agropecuária Brasileira, 41, 1193-1198. http://dx.doi.org/10.1590/S0100-204X2006000700017

[27] Uebele, M.C. (2002) Demographic Patterns of Tillering and Forage Production in Pastures Mombaçagrass Undergoing Intermittent Stocking Regimes. Master's Dissertation, Escola Superior de Agricultura Luiz de Queiroz, Piracicaba. 
Scientific Research Publishing (SCIRP) is one of the largest Open Access journal publishers. It is currently publishing more than 200 open access, online, peer-reviewed journals covering a wide range of academic disciplines. SCIRP serves the worldwide academic communities and contributes to the progress and application of science with its publication.

Other selected journals from SCIRP are listed as below. Submit your manuscript to us via either submit@scirp.org or Online Submission Portal.
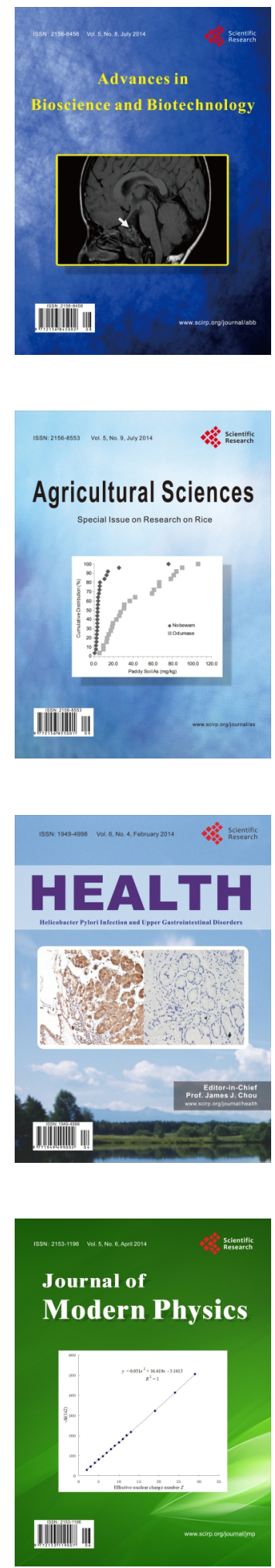
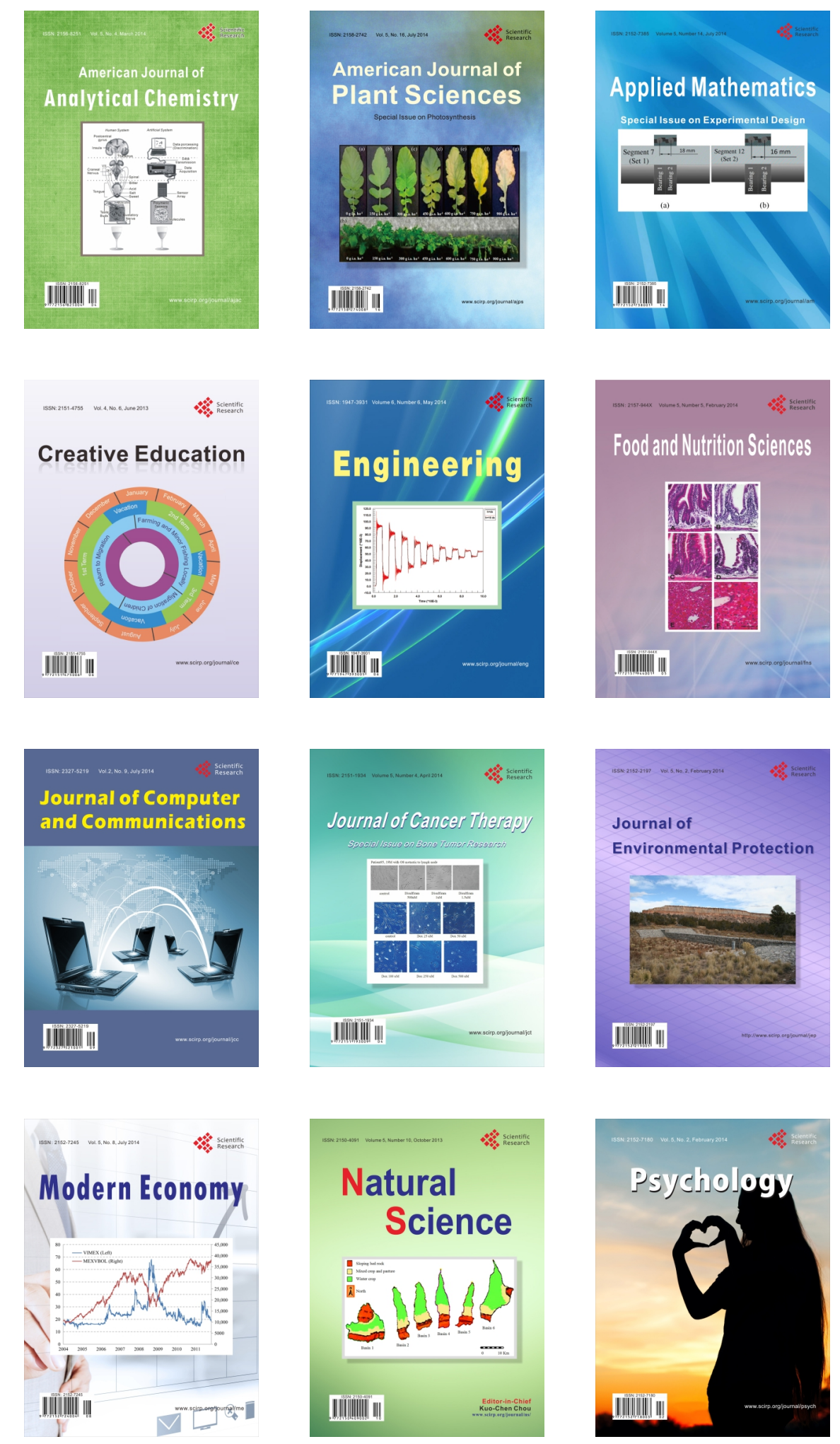